\title{
Tax Incentives, Bequest Motives, and the Demand for Life Insurance: Evidence from two Natural Experiments in Germany
}

\author{
Nicolas Sauter \\ Jan Walliser \\ Joachim Winter
}

CESIFo WORKING PAPER NO. 3040

CATEGORY 1: PUBlic FinANCE

APRIL 2010

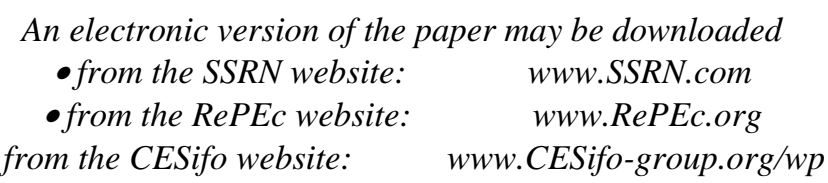




\title{
Tax Incentives, Bequest Motives, and the Demand for Life Insurance: Evidence from two Natural Experiments in Germany
}

\begin{abstract}
Whole life insurance plays an important role in household saving. However, empirical evidence on its determinants is scarce. This paper studies two natural experiments to identify the effects of tax incentives and bequest motives on life-insurance demand. An unanticipated tax reform in 2000 halved the tax exemption limit for capital income in Germany. We document that the demand for life insurance reacted strongly to this change. With regard to bequest motives, we analyze the demand for life insurance in the former German Democratic Republic (GDR). Relative to market-based economies, the socialist GDR can be viewed as an experimental institutional setting where life-insurance demand was not influenced by tax considerations which allows us to isolate bequest motives while controlling for life-cycle and precautionary motives. We find a significantly higher ownership probability among households with children and a high regard for the family, confirming bequest motives in lifeinsurance demand.
\end{abstract}

JEL-Code: D91, C25, D14, G11.

Keywords: savings, life insurance, capital income taxation, bequests.

Nicolas Sauter
University of Munich
Germany

Jan Walliser

The World Bank

Washington, $D C$

\author{
Joachim Winter \\ Department of Economics \\ University of Munich \\ Ludwigstrasse 28 \\ Germany-80539 Munich \\ winter@lmu.de
}

This version: February 15, 2010

We would like to thank Thiess Büttner for helpful comments. Financial support from the Deutsche Forschungsgemeinschaft through GRK 801 is gratefully acknowledged. The views expressed in this paper do not necessarily represent those of the World Bank, its Executive Board, or the governments the latter represents. 


\section{Introduction}

Life insurance is one of the most popular financial assets owned by a large number of households in many countries (Guiso, Haliassos, and Jappelli, 2002). In its simplest form - term life insurance - it enables the policyholder to pass on bequests to children or other beneficiaries if he or she dies before a certain point in time (the end of the term). However, in many countries, life insurance products are a popular savings vehicle for old age as well. Under whole life insurance contracts, the insurer faces a certain liability over the whole lifetime of the insured, for which the insurer accumulates reserves during the working life of the policyholder. Typically, the policyholder has the right to withdraw the savings component in old age, provided he or she survives. As a result, under whole life insurance term life insurance provisions are coupled with a savings contract. This savings component of whole life insurance often receives tax preferences. Studying the demand for whole life insurance ownership has significant appeal as it allows testing for both the importance of tax incentives and bequest motives in households' savings decisions. This paper explores these two aspects through a study of whole life insurance ownership in Germany.

Interest in providing incentives for retirement savings (including through whole life insurance) intensified during the past few years. Many governments have already reduced the generosity of existing pay-as-you-go pension systems, or are considering doing so as their population ages. Hence, households are increasingly pressed to increase their private savings portfolio in order to sustain the standards of living during retirement, and governments seek to encourage these savings through preferential tax rules. The empirical evidence on the importance of such tax incentives is, however, inconclusive. Scholz (1994) finds little evidence that households modified their portfolios in response to the 1986 US Tax Reform Act. Also, Jappelli and Pistaferri (2003, 2007) do not find significant changes in the demand for life insurance and mortgage debt by those households most affected by incremental tax reforms in Italy. On the other hand, several studies that use cross-sectional data report a positive correlation between marginal tax rates and investments channelled into tax-sheltered assets: Alan et al. (2009) for Canada, Alan and Leth-Petersen (2006) for Denmark, Alessie, Hochguertel, and van Soest (1997) for the 
Netherlands, Agell and Edlin (1991) for Sweden, Banks and Tanner (2001) for the UK, and finally King and Leape (1998), Poterba (2002), and Poterba and Samwick (2003) for the US. Yet in cross-sections, it is difficult to disentangle genuine variation in marginal tax rates for given income from genuine variation in income for given tax rates, because after-tax-yields depend on changing marginal tax rates which in turn depend on income levels. ${ }^{1}$

Our analysis contributes to the literature on taxation and portfolio choice by exploiting a natural experiment that induced changes in tax incentives for investing in whole life insurance. In Germany, a tax reform in 2000 enables us to contrast life-insurance demand among those households affected by the reform with that of a control group that remained unaffected. The changes in the tax law reduced the limit on tax exemptions and created a strong incentive among households that were fully exempt from capital income taxation before the reform to shelter their savings from taxation by investing in (tax-exempt) life insurance contracts afterwards. In contrast to the prior literature, this allows us to analyze the impact of changing tax incentives at the margin rather than relying on incremental changes in after-tax returns.

A second aspect of life-insurance demand studied in this paper relates to the importance of bequest motives for saving decisions. Empirical studies disagree about the strength of bequest motives. Estimates of the share of bequests in aggregate private savings range from 17 (Modigliani, 1988) to 46 percent (Kotlikoff and Summers, 1981). Cross-country evidence shows that life-insurance demand is higher in countries with a high dependency ratio (Browne and Kim, 1993), high income per capita, low inflation, and a high degree of banking sector development (Beck and Webb, 2003). At the household level, Bernheim (1991) finds that a significant fraction of life-insurance demand and consumption can be motivated by the desire to leave bequests to one's children. Kopczuk and Lupton (2007) estimate that households with a bequest motive save about 25 percent more, whereas Hurd $(1987,1989)$ finds that the marginal utility from bequests in a consumption-savings model is close to zero. Data from direct survey questions on the intention to leave a bequest has been used by Laitner and Juster (1995) and Jürges (2001).

\footnotetext{
${ }^{1}$ In his seminal contribution, Feldstein (1976) uses labor income as a proxy for the marginal tax rate.
} 
Although both find that bequest motives shape savings behavior, altruism toward one's children appears to be of only minor importance. All these studies suffer from the difficulty to distinguish true bequest motives from other savings motives, such as tax, life-cycle, or precautionary motives. In this paper, we can identify the importance of bequest motives in the demand for life insurance by exploiting the natural experiment of the division of Germany into two separate states. Owing to the absence of tax incentives and the limited number of consumption and savings possibilities in the former German Democratic Republic, we can use data from a household survey conducted in 1990 (the last year of the GDR's existence) to quantify the impact of bequest motives on the demand for life insurance while controlling for life-cycle and precautionary savings motives.

Our key empirical findings confirm the predictions from a stylized theoretical model of life-insurance demand. First, the probability to own tax-exempt whole life insurance contracts increases by 5.2 percent among households affected by the tax reform in 2000 (i.e., among those households loosing their exemption from capital income taxation). Second, there is also strong indication that households in the former GDR - where lifeinsurance demand was not diluted by tax considerations - purchased life insurance to bequeath wealth to their children, whereas provision for non-working partners seems to play a lesser role.

This paper proceeds by discussing some key theoretical predictions from a formal model of life-insurance demand in section 2. Section 3 describes the data. Section 4 analyzes the impact of the German tax reform in 2000 on life-insurance demand. In section 5, estimates of the strength of bequest motives in GDR life-insurance demand are reported. Section 6 provides a summary and conclusions.

\section{A life-cycle model with tax incentives and bequests}

A number of papers in the economics literature model the demand for term life insurance. Term insurance pays a benefit if the insured dies before a certain date. The first model for term life insurance in a continuous time setting is Yaari (1965). Fischer (1973) develops a life cycle model of term life-insurance demand in discrete time and discusses the allocation 
of insurance purchases over the life cycle. Less common is the modelling of whole life insurance. Whole life insurance requires the build-up of insurance reserves because the insured typically pays premiums only during working life. These premiums must also finance later obligations. Many whole life insurance contracts enable the insured to take out those reserves (the cash value or surrender value) after a certain age, and therefore resemble a combination of term life insurance with a savings plan. Babbel and Ohtsuka (1989) build a three-period model with uncertainty about future rates of return and health status that allows for simultaneous purchase of term life insurance and whole life insurance, overcoming the problem that whole life insurance is usually dominated by a combination of term life insurance and a savings plan. However, their model is inherently difficult to solve even with sophisticated numerical methods. Moreover, Babbel and Ohtsuka do neither capture the tax preferences of life insurance nor consider the effect of public pension programs on life-insurance demand.

This paper derives life-insurance demand in a model with a "joy-of-giving" bequest motive, following the standard approach in the literature (one exception is Lewis, 1989). The model has three periods and three types of assets, life insurance, bonds, and public pensions. Life insurance is modelled as a combination of term life insurance and a savings plan. Our specification incorporates the salient features of the German tax and pension system. ${ }^{2}$

In the three-period model, the timing convention used is as follows: consumption streams in the three periods are indexed by 0,1 , and 2 , and end-of-period bequests are indexed by $1,2,3$, respectively. A consumer can use his income to purchase life insurance $L$ at a premium $Z$ per unit, or save an amount $S$ of bonds. Bonds earn a rate of return $r$ and the return is subject to a capital income tax of $\tau^{C}$. Moreover, individuals must contribute to a public pension system with a payroll tax $\tau^{S}$ and they receive pensions in old age. The pension system has an internal rate of return of $g$.

\footnotetext{
${ }^{2}$ This model was first presented by Walliser and Winter (1999).
} 
More formally, consider the following expected utility function in consumption, $c$, and bequests, $b$ :

$$
W(c, b)=\sum_{t=0}^{2} \frac{1}{1-\gamma}\left(\frac{1}{1+\delta}\right)^{t}\left[c_{t}^{1-\gamma}+\eta_{t+1} b_{t+1}^{1-\gamma}\left(1-\pi_{t+1}\right)\right] \prod_{s=1}^{t} \pi_{s},
$$

where $\delta$ represents the pure rate of time preference, $\gamma$ is the risk aversion parameter of the constant relative risk aversion utility function, $\eta$ is the weight on bequests and $\pi_{t}$ is the probability to survive at the beginning of period $t$. Since death at the end of period 2 is certain, $\pi_{3}=0$.

To simplify notation, let $1+r=R, 1+r\left(1-\tau^{C}\right)=R^{C}$, and $1+g=G$. The utility maximization is then subject to the following budget constraints in the first two periods $(t=0,1)$ :

$$
\begin{aligned}
& c_{t}=w_{t}\left(1-\tau^{S}\right)-Z_{t} L_{t+1}-S_{t+1}+S_{t} R^{C}+\alpha L_{t} \\
& b_{t+1}=S_{t+1} R+L_{t+1} .
\end{aligned}
$$

Here, $w$ stands for labor earnings. $\alpha$ is the exogenous savings portion of the life insurance contract - if the policy holder survives, a fraction of the insurance sum (the cash value) can be withdrawn. Note also that in case of death the estate receives the full rate of return on bonds, implicitly assuming that there are no estate taxes to be paid.

Consumers retire in their third period of life and receive a public pension. Since life ends with certainty after period 2, there is no role for life insurance in the last period. Consequently, the budget constraints are as follows:

$$
\begin{aligned}
& c_{2}=\tau^{S}\left(w_{0} G^{2}+w_{1} G\right)-S_{3}+S_{2} R^{C}+\alpha L_{2} \\
& b_{3}=S_{3} R .
\end{aligned}
$$

The first order conditions imply the following relationship between consumption in different periods and consumption and bequest for $t=1,2$ :

$$
\frac{c_{t}}{c_{t-1}}=\left[\frac{1-Z_{t-1} R}{\frac{\pi_{t}}{1+\delta}\left(R^{C}-\alpha R\right)}\right]^{-\frac{1}{\gamma}}
$$

and

$$
\frac{c_{t}}{b_{t}}=\left[\frac{\left(1-\pi_{t}\right) \eta_{t}\left(1-Z_{t-1} R\right)}{\frac{\pi_{t}}{1+\delta}\left(R^{C} Z_{t-1}-\alpha\right)}\right]^{-\frac{1}{\gamma}}
$$


Bequests at the end of period 2 are simply:

$$
b_{3}=c_{2}\left(R \eta_{3}\right)^{\frac{1}{\gamma}}
$$

Using equations (6), (7) and (8), the consumer's maximization problem can be solved recursively. The algebraic solution is fairly complicated and therefore provides few immediate insights (see the Appendix). However, the first-order conditions offer some qualitative predictions for variations in key variables. In general, people buy life insurance for three reasons in our model: first, life insurance enhances bequeathable wealth and is therefore valuable especially at younger ages when savings are still small. Second, life insurance has a tax advantage over other savings. Third, if the consumer considers public pension coverage as too generous he can de-annuitize by purchasing life insurance. ${ }^{3}$

Consider first the impact of tax changes on portfolio choices. Suppose two households have the same household income but differ in their tax rate on capital income $\tau^{C}$. According to equations (6) and (7), the two households would differ in their consumption, bequest, and portfolio choices. As indicated by equation (6), a household facing a lower tax rate (higher $R^{C}$ ) would choose a steeper consumption profile because higher after-tax rates of returns make future consumption "cheaper." As shown in equation (7), that household would also choose to bequeath less than the household facing higher tax since lower taxes make future consumption cheaper but do not affect the implicit price for bequests. Equations (6) and (7) and the budget constraints also imply a different portfolio choice. For reasonable parameter choices, the household with lower tax rates can satisfy (6) and (7) simultaneously only if it holds less life insurance and more savings than the household with higher tax rates. Lowering life insurance by a dollar and increasing savings by a dollar in period 0 reduces consumption by $Z_{0}-1$ dollars. Under the assumption that insurance is fair, $Z_{0}=\frac{1-\pi_{1}}{R}+\frac{\alpha \pi_{1}}{R}$, which is less than 1 , the reallocation thus reduces resources in the first period. It increases resources in the following period by

\footnotetext{
${ }^{3}$ Yaari (1965) discusses why in perfect markets purchasing life insurance is equivalent to purchasing a negative annuity.
} 
$R^{C}-\alpha$ which exceeds 1 for reasonable parameter choices. ${ }^{4}$ Moreover, such a reallocation increases bequests by $R-1$, which is smaller than $R^{C}-\alpha$ as long as $(R-1) \tau^{c}+\alpha$ is less than 1 , which again is the case for reasonable parameter choices. In summary, reallocating a dollar from life insurance to savings lowers current resources, increases future resources, and increases future resources for consumption more than for bequests.

An analogous argument holds for changes in the parameter $\alpha$ that determines the savings content of whole life insurance. Lowering $\alpha$ has the same effect on first-order conditions as lowering the tax rate on capital income. Thus, quite intuitively, equations (6) and (7) together with the budget constraints also predict that lowering the implicit savings portion of life insurance leads households to shift more resources away from life insurance and towards regular savings.

As equation (7) demonstrates, increasing the strength of bequest motives leads to the result that the relative size of bequest to consumption must increase, while the relative size of consumption in different periods remains constant according to equation (6). Clearly, the less costly way to increase bequests is to purchase more life insurance. However, unlike the previous results, it depends on specific parameter values whether both saving and life insurance increase or whether life-insurance demand increases and savings falls.

Finally, varying the size of the public pension system also matters for both saving and life insurance. As is well known, public pensions crowd out private savings in a lifecycle model. To the extent that life insurance is a savings instrument, one would therefore expect life-insurance demand to fall. However, for people who feel that the public pension is too generous, purchasing more life insurance is a way to increase bequest and reduce the "overannuitization". Thus, the precise effect of public pension coverage on life-insurance demand depends on the relative magnitude of the savings and bequest motives.

To summarize, the stylized life-cycle model presented in this section delivers two main testable predictions regarding life-insurance demand. First, controlling for income, people facing lower relative tax rates on other savings should purchase less whole life

\footnotetext{
${ }^{4}$ For example, assuming interest rates of three percent per year, a value of $\alpha$ of around 0.2 implies in a three period model that roughly 80 percent of life insurance premiums contribute to the accumulation of reserves in the first period of life.
} 
insurance to accommodate a steeper consumption profile. Second, people with stronger bequest motives, for example married people or households with children, should have stronger incentives to purchase life insurance. The impact of public pension coverage on life-insurance demand is ambiguous.

\section{The data}

The German Socioeconomic Panel (GSOEP) offers a unique opportunity to study the effect of tax reform and bequest motives on the demand for life insurance. It is the only dataset that contains annual information about life insurance ownership and portfolio choice of German households that spans from pre- to post-reform years. We can study portfolios in the territory of the GDR, where the first GSOEP interview was conducted in 1990 (prior to reunification) with a sample of around 2000 households. The first survey in the West was conducted in 1984. Since then, the sample has been significantly increased in 1998 and 2000. Descriptive evidence for the development of the sample is provided in table $2 .^{5}$

Households are asked annually if they owned one or more life insurance policies in the previous year. Thus, we only use observations for households that take part in two successive surveys. If not otherwise stated, socioeconomic characteristics are proxied by the household head. We approximate marginal tax rates by re-calculating each household's taxable income from its (estimated) tax payments, using the official formulas of the federal tax office. ${ }^{6}$ A 1 unit change in taxable income is simulated in order to approximate the marginal tax rate. Socioeconomic characteristics are proxied by the household head.

\footnotetext{
${ }^{5}$ The Add-On package PanelWhiz for Stata (http://www.PanelWhiz.eu) has been used for extracting the data. See Haisken-DeNew and Hahn (2006) for details. The PanelWhiz generated do file to retrieve the data used here is available upon request. Any data or computational errors are our own.

${ }^{6}$ The GSOEP estimates of total tax payments are based on Schwarze's (1995) approach. Schwarze adds up the incomes of all household members and applies standard deductions based on the socioeconomic status of the household.
} 


\section{Tax incentives}

Life insurance is the second most common asset after savings accounts in Germany. In 2007, 15.6 percent of total private wealth, amounting to 716 billion Euro, was allocated to life insurance (Deutsche Bundesbank, 2008). Overall, 93.9 million life insurance policies existed, of which 7,617,400 had been sold in that year (Gesamtverband der Deutschen Versicherungswirtschaft, 2008). On the flipside of the market, around 49 percent of households own life insurance policies. ${ }^{7}$

One of the main reasons for this unusually high popularity in Germany is suspected to be the favored fiscal treatment of life insurance policies (and whole life insurance in particular). First, returns on life insurances are tax exempt if the contract lasts for at least 12 years, premiums are paid during at least five years, and the term life insurance component amounts to at least 60 percent of the total benefit paid out at the end of the contract. Second, annual contributions to whole life and term life insurance contracts are tax deductible. However, this is typically of little benefit for employees, as they reach the deductibility cap with their obligatory contributions to the social security system. Obligatory contributions are smaller for civil servants and the deductibility cap is higher for the self-employed, who are generally exempt from contributing to the public pension system and must provide for their own retirement income and survivor's benefits (Sommer, 2007). Our analysis includes controls for the self-employed and civil servants to account for these variations in effective deductability. Finally, in the case of bequests, only twothirds of the cash value of life insurance policies are taxed. It is even possible to avoid estate taxes altogether if, for instance, one spouse pays premiums into a life insurance policy owned by the other spouse, who also is the beneficiary if she dies early.

\section{Insert figure 1 about here.}

The 2000 tax reform had a major impact on the treatment of whole life insurance, and it had a visible effect on whole life insurance sales trends. Figure 1 plots the development of sales of new life insurance contracts between 1995 and 2003 in Germany. During the

\footnotetext{
${ }^{7}$ Authors' calculation based on data from the GSOEP. Typically, life insurance policies have one beneficiary, so that it makes sense for households with several children to invest into several policies.
} 
entire period, sales of term life insurance policies are relatively constant around 700,000. However, sales of new whole life contracts spike in 1999, indicating an anticipation effect of the tax reform. As taxpayer groups have been affected differently by the reforms, in this paper we can clearly identify the response of households' savings allocation to changes in after-tax yields.

\subsection{The tax reform of 2000}

Germany taxes all interest and dividend income exceeding a certain threshold at the households' marginal tax rate. The development of this threshold, the so-called Sparerfreibetrag (tax exemption limit), is shown in table 1 for the period from 1996 and 2001. In March 1999, a law was passed, cutting the tax exemption limit from DM6,000 $(12,000)$ to DM3,000 (6,000) for singles (couples) from January 1, 2000 onward. We suspect that households between the old and the new tax exemption limit were disproportionately affected by this reform. As their capital returns were fully exempt from taxation beforehand, the reform created a strong incentive to shelter their savings from taxation by purchasing whole life insurance when the reform was announced. In other words, if these households are responsive to the relative tax treatment, we should see a disproportionate increase of life insurance purchases among the group threatened to have their regular savings income taxed by the reduction of tax exemptions. In what follows, we denote households belonging to this category as the "treatment group".

In order to identify the treatment group, we use survey responses on capital income levels. One quarter of all households report their exact income from interest and dividends in the survey, whereas three quarters indicate on an ordinal scale if their capital income is less than 500, between 500-2,000, 2,000-5,000, 5,000-10,000, or above 10,000 DM. These ordinal thresholds reduce precision of estimating the response to tax changes, biasing the results against finding significant differences between groups. We use a differencein-differences estimator to test if the treatment group is more likely to own one or more (tax-exempt) life insurance policies from 2000 onward.

Insert table 1 about here. 
Our empirical analysis is subject to two additional considerations. First, in June 1999, the government proposed to abolish the tax exemption on life insurance returns by end 1999. Many households were concerned about losing a tax-favored savings opportunity, boosting sales of new contracts by 38.7 percent in 1999. Dolle-Helms (1999a, 199b) provides anecdotal evidence that last minute purchases in 1999 were mainly driven by tax motives. The reform eventually failed in the upper house of parliament (Bundesrat) in mid-December and many investors (unsuccessfully) claimed their money back. All households, including those above the tax exemption limit, were also potentially affected by the proposed and later dropped reform in 1999. To identify the impact of the 2000 tax reform that affected the relative tax treatment of life insurance and other savings for people below the DM6,000 limit we test if, from 1999 onward, the ownership probability among the treatment group increases relative to wealthier households whose capital income was already above the DM6,000 exemption limit. The implicit underlying identifying assumption is that both the treatment and control group responded equally (in proportional terms) to the announced phasing out of tax advantages for life insurance. Second, the 2000 reform may also have had an impact on those households already paying taxes on capital income since their total tax exempt amounts fell. However, these households would not be at the margin of being subject to paying capital income taxes. If tax incentives matter, households with high capital incomes should already have invested into life insurance before the reform in order to shelter their savings from taxation, and the response would be intra-marginal.

\section{Insert table 2 about here.}

Descriptive evidence in table 2 confirms that indeed significant changes only occurred in the treatment group. Life insurance ownership rates remained constant among households below the new tax exemption limit and above the old exemption limit. However, the ownership rate increased strongly from 62.5 to 69.7 percent in the treatment group in 1999. This shows that households affected by the tax reform in 2000 advanced their investments and stocked up on (tax-exempt) life insurance policies before the reform came into effect. 


\subsection{Empirical results}

We estimate a reduced-form model in order to analyze the effect of tax reform on lifeinsurance demand. In particular, a before-and-after comparison is made between a control group of investors that are unaffected by the reform with a treatment group that is affected by the new tax regime, using a difference-in-differences estimator on repeated cross-sectional data. We denote individual $i$ 's binary indicator for the treatment group as $G_{i}$. For the reform in 2000, the treated are defined as $G_{i t}=1\left\{\right.$ limit $^{\text {new }} \leq I N C_{i t}^{C A P} \leq$ limit $\left.{ }^{\text {old }}\right\}$, where $I N C_{i t}^{C A P}$ denotes total capital income. $T_{i}=1\{t \geq 1999\}$ is a time dummy indicating the anticipated reform. To ease the notational burden, we introduce the shorthand $Y_{i \in g, t}$ for $Y_{i} \mid G_{i}=g, T_{i}=t$. The potential outcomes with and without treatment are $Y_{i}^{1}$ and $Y_{i}^{0}$ respectively. The model for the outcome without intervention is given by

$$
Y_{i}^{0}=\alpha T_{i}+\beta G_{i}+\epsilon_{i}
$$

where $\epsilon_{i} \perp\left(T_{i}, G_{i}\right)$. The model for the treatment group is

$$
Y_{i}^{1}=\alpha+\beta+\tau^{D i D}+\epsilon_{i}
$$

In the absence of intervention, the average outcome for the treatment group is $E\left[Y_{i \in 1,1}^{0}\right]=$ $E\left[Y_{i \in 1,0}\right]+E\left[Y_{i \in 0,1}\right]-E\left[Y_{i \in 0,0}\right]$. The average treatment effect on the treated is defined as

$$
\begin{aligned}
\tau^{D i D} & =E\left[Y_{i \in 1,1}^{1}\right]-E\left[Y_{i \in 1,1}^{0}\right] \\
& =E\left[Y_{i \in 1,1}\right]-E\left[Y_{i \in 1,0}\right]-\left(E\left[Y_{i \in 0,1}\right]-E\left[Y_{i \in 0,0}\right]\right) .
\end{aligned}
$$

This estimator requires three identifying assumptions. First, we assume that the tax reform is exogenous to the ownership decision. Investors were hit by surprise, when the tax reforms were announced in 1999, since the reforms were not mentioned in election campaigns or the coalition program of the incoming government. We can also safely exclude the possibility of policy endogeneity, because the reform was not introduced to change the demand for life insurance by different taxpayer groups. It was part of a major tax reform package with the aim of broadening the tax base. Second, we assume that there are no group specific trends in life insurance ownership. This assumption guarantees that the counterfactual of the treated can be inferred from the time trend of 
the control group. As discussed above, this assumption certainly holds for households above the new exemption limit. Third, we assume that the tax reform is exogenous with respect to sample composition. Essentially, this requires that household income as well as interest and dividend income did not change as a result of the tax reform itself. This condition would fail if interest and dividend income fell when a household buys life insurance. However, households typically pay annual premiums of less than DM2,000 (Sommer, 2007) which would only marginally affect total capital income at reasonable interest rates. In any event, the presence of such wealth effects would rather bias the results against our hypothesis.

\section{Insert table 3 about here.}

The upper panel of table 3 reports the average effects of the tax reform, using a sample from three years before and three years after the announcement of the reform. ${ }^{8}$ While ownership rates of life insurance fell among households in the control group from 2000 onwards, an increase by 4.5 percent can be observed for the treatment group. The difference-in-differences estimate according to equation (9) is 5.7 percent for the full sample and 5.9 percent for households above the new exemption limit. ${ }^{9}$

These estimates may be biased for two reasons. First, the estimated probabilities of investing into life insurance do not necessarily lie in the $[0,1]$ interval. Second, the effects could be blurred because other determinants account for different behavior across groups. Thus, we translate the difference-in-differences approach into a probit regression that imposes bounds on the estimated probabilities and accounts for other covariates.

The model for the outcome without intervention is given by

$$
P\left(Y_{i}^{0}=1 \mid G_{i}, T_{i}, \boldsymbol{x}_{i}=\Phi\left(\alpha T_{i}+\beta G_{i}+\boldsymbol{x}_{i} \boldsymbol{\delta}\right),\right.
$$

where $\boldsymbol{x}$ is a vector of additional regressors and $\boldsymbol{\delta}$ denotes the vector of associated parameters. The model for the treatment group is

$$
P\left(Y_{i \in 1,1}^{1}=1 \mid \boldsymbol{x}_{i}\right)=\Phi\left(\alpha+\beta+\gamma+\boldsymbol{x}_{i} \boldsymbol{\delta}\right)
$$

\footnotetext{
8 The analysis controls for the approximated marginal tax rate of the household, which incorporates the changes due to the 2001 tax reform.

${ }^{9}$ Estimates are similar, if all observations for the transition year 1999 are dropped.
} 
Puhani (2008) shows that in a nonlinear model, such as probit, the treatment effect on the treated should not be confused with the cross-derivative of the interaction term (Ai and Norton, 2003). Based on the standard probit difference-in-differences model

$$
P\left(Y_{i}=1 \mid G_{i}, T_{i}, x_{i}\right)=\Phi\left(\alpha T_{i}+\beta G_{i}+\gamma T_{i} G_{i}+\boldsymbol{x}_{i} \boldsymbol{\delta}\right)
$$

a consistent estimator of the treatment effect is

$$
\begin{aligned}
\widehat{\tau}^{D i D} & =E\left[Y_{i \in 1,1}^{1} \mid \boldsymbol{x}_{i}\right]-E\left[Y_{i \in 1,1}^{0} \mid x_{i}\right] \\
& =\frac{1}{N} \sum_{i=1}^{N}\left(\Phi\left(\widehat{\alpha}+\widehat{\beta}+\widehat{\gamma}+\boldsymbol{x}_{i} \widehat{\boldsymbol{\delta}}\right)-\Phi\left(\widehat{\alpha}+\widehat{\beta}+\boldsymbol{x}_{i} \widehat{\boldsymbol{\delta}}\right)\right)
\end{aligned}
$$

Hence, the treatment effect is zero if and only if the coefficient $\gamma$ is zero. We apply the delta-method to infer statistical significance of the average treatment effect in small samples. Different from the linear model, identification is not provided by the assumption that the cross difference $\gamma$ is zero for the expected potential outcome $Y_{i}^{0}$, because group and time differences in the conditional expectation of the potential outcome $Y_{i}^{0}$ are not constant in the nonlinear probit model. However, a nonlinear parametric restriction on that cross-difference guarantees that all expected outcomes (factual or counterfactual) are bounded as required (Athey and Imbens, 2006).

\section{Insert table 4 about here.}

Table 4 reports summary statistics of the additional covariates included in the regression. In particular, we include the marginal tax rate to control for differences in after-tax returns. We proxy for the household's net labor income via binary indicators for deciles of the income distribution. Dummies for house ownership as well as interest and dividend returns control for household wealth. Furthermore, martial status and a binary indicator for households with one or more children, as in Hurd (1987, 1989), capture bequest motives. Dummies for employment status, civil servants and the self-employed reflect specific characteristics of the German tax and public pension system. Finally, the model includes gender, education, and linear and non-linear terms of the age of the household head. We use data for three years before and after the reform. The full sample consists of 44,540 observations and 2,419 if we constrain the analysis to households above the new exemption limit. 
Table 5 reports average marginal effects for continuous and dummy variables. The interaction effect $\widehat{\tau}^{D i D}$ is statistically significant at the 5 percent level in both equations. According to equation (10), the tax reform increased ownership among households affected by the reform by 5.2 percent. The estimate is 8.9 percent for the restricted sample in column (2). Furthermore, the estimates of the marginal effects in columns (1) and (2) show a highly significant positive correlation between marginal tax rates and investment into life insurance. The model in column (1) suggests that an increase of the marginal tax rate by 10 percentage points increases the ownership probability by 3.3 percentage points. Also, there is evidence that the self-employed, who have larger tax incentives and lower pensions, are more likely to own life insurance policies. We find no evidence that life insurance ownership is higher among civil servants, who typically receive relatively generous survivor benefits.

Our results contrast with Jappelli and Pistaferri (2003, 2007) who do not find that tax incentives matter for life-insurance demand in Italy. However, anecdotal evidence suggests that sales agents exploited the favorable market situation in Germany deriving from the tax changes, whereas Italian insurers lacked the incentive to point out the effects of the tax reform among potential investors. Moreover, the tax incentive resulting from incremental changes in after-tax yields in Italy might be too small to induce significant changes in investment behavior if inertia is present in portfolio adjustments.

The findings from the natural tax experiment are less clear with regard to bequest motives. Although there is strong evidence that married couples invest into life insurance, we cannot confirm that households with children are more likely to own life insurance. These mixed results are much in line with the previous literature that finds evidence in both directions. One reason for these ambiguous results stems from the impossibility of past studies to neatly single out bequest motives from other forms of savings motives. For instance, we would be unable to identify bequest motives in the presence of strong tax incentives if households with children were liquidity constrained in the short run. Also, households with children could use the separate tax exemption limits for their children in order to avoid capital income taxation and thereby distort the separate identifiability of 
tax and bequest motives. Yet the empirical evidence for the importance of tax incentives among the relevant households persuasively shows that taxation is a significant factor in households savings decisions. In order to identify bequest motives, however, an additional experimental setting is needed that eliminates distortionary tax effects.

\section{Bequest motives}

Our identification strategy for bequest motives in life insurance relies crucially on the assumption that the specific institutional environment in the GDR allows us to control for the main alternative savings motives discussed in the literature such as tax, life-cycle, and precautionary savings motives (Browning and Lusardi, 1996). The following section describes the peculiarities of the market for life insurance in the GDR as it prevailed until German unification in late 1990. Throughout the section, bequest motives are defined as a willful desire to hand on one's wealth to close relatives or friends during lifetime or posthumously.

\subsection{Savings environment in the GDR}

Whole life insurance played an important role in household portfolios in the GDR. Before reunification, East Germans could only chose between investing into savings accounts or life insurance. Therefore, life insurance was typically considered a long-term savings contract (with an additional term life insurance option). While savings accounts offered a unitary interest rate of 3.25 percent (Schwarzer, 1999), calculatory returns on life insurance were about 3.5 percent plus a 15 percent terminal bonus. The only provider of insurance was the Staatliche Versicherung der DDR, of which Allianz acquired the private client business after reunification. ${ }^{10}$

Tax incentives. A major advantage of studying life-insurance demand in the GDR is that returns on savings accounts and insurances were fully exempt from taxation. Also, the beneficiary of a life insurance policy was exempt from death taxes (Schulze, 1970).

${ }^{10}$ We thank Dr. Michael Lehner from Allianz for providing detailed information about the life insurance market in the GDR. 
Different from all existing studies on bequest motives, our analysis will therefore not be diluted by tax considerations.

Life-cycle savings motives. Another key feature of savings decisions in the GDR is that consumption possibilities were very limited, enabling us to control for ownership of all goods and services for which GDR citizens needed to accumulated large deposits. In particular, we can control for the five main life-cycle and down-payment motives: First, we can condition for life-cycle saving effects through linear and nonlinear terms of age as well as an indicator for the retirement status of the household head. Around 40 percent of all retirees participated in an additional retirement pension supplement plan. However, average pensions were about 450 (550 with the supplement) Mark in 1986, compared to an average labor income of 960 Mark (Dabbert, 1992). ${ }^{11}$ Hence, the elderly had to rely on their savings for a sufficient retirement income. Second, households had little incentive to use life insurance to accumulate deposits for buying an own apartment or house. The communist government restricted ownership of private property and largely subsidized construction of rental housing. Also, it was very cheap to live in a rented apartment, since rents were fixed by the central government and too low to recover maintenance cost (Manzel, 1992). Third, only few durables required large downpayments. There is anecdotal evidence that life insurance contracts were used to buy cars. This was a sensible thing to do, because the average duration of life insurance policies, 11.6 years, matched the average delivery time for a car, 13.5 years (Wolle, 1999). ${ }^{12}$ The only other durables for which large deposits were necessary are motorcycles and weekend houses (Datschas). The data allow us to control for these three durables when estimating the strength of bequest motives. Fourth, we rule out the possibility that citizens used life insurance as a means to save for travel. The duration of life insurance policies does typically not match the decision to travel. Moreover, travel restrictions were not lifted before the 1970s and even then GDR citizens could only travel to four foreign countries without a visa

11 The Deutsche Mark (DM) should not be confused with the Mark which was the official currency of the GDR. Mark (East) were exchanged 1:1 for Deutsche Mark (DM) in 1990. However, the cash value of life insurance policies and savings above 4,000 Mark were exchanged 2:1.

${ }^{12}$ A fashionable nickname for life insurance used to be Trabi-Sparvertrag (savings contract for a Trabant ("Trabi") car). 
(Czechoslovakia, Hungary, Poland, Bulgaria). Often, travelling was further complicated by scarce foreign exchange (Saretzki and Kohn, 1992). Other leisure activities did typically not require larger amounts of money. Yet some social activities may affect mortality risk (sports) or provide an information network that increases the awareness for life insurance products. The regression includes indicators for households that go at least once a month to the cinema or theater, a cultural event, the church, do active sports, visit friends, or help neighbors. Fifth, private spending on education did not exist under the communist regime in the GDR. The government fully paid for primary and higher education as well as vocational training (Marggraf, 1992). Access to higher education required membership in the GDR youth organization $(F D J)$, and favored entry for children from working class backgrounds.

Precautionary savings motives. Economists disagree sharply as to why people bequeath wealth. In contrast to the view that bequests are intentional, Hurd (1987) suggests that bequest are only an accidental remnant of precautionary savings. Yet the social system in the GDR gave very few reasons to accumulate wealth as a buffer for uncertain times. We believe that our regression captures the remaining precautionary motives and therefore yields reliable estimates of the strength of bequest motives. First, East Germans did not have to hedge against income fluctuations, because full employment was constitutionally guaranteed. Fuchs-Schündeln and Schündeln (2005) also argue that income differences and volatility were very low. Second, we control for the self-assessed health status of each individual, which could affect precautionary savings, although health services were fully provided by the central government as well. ${ }^{13}$ Third, respondents were asked if they are dissatisfied or very dissatisfied with the social benefits available in the GDR. Dissatisfaction could denote a larger demand for precautionary savings. Finally, the survey elicited a proxy for individual risk attitudes using a direct question on how willing the respondent is to take on risks, with responses given on an eleven-point scale.

Bequest motives. If bequests are intentional, they may either reflect altruism (Tomes, 1981), self-interested exchange with one's heirs (Bernheim, Shleifer, and Sum-

13 The questionnaire reads, "How satisfied are you with your health?" Answers are given on an elevenpoint scale. 
mers, 1985), or the outcome of an intra-household reallocation of incomes (Gandolfi and Miners, 1996). Gandolfi and Miners argue that families insure the labor income of the main bread-earner through life insurance. We proxy for potential reallocation motives by the wife's labor force participation status and the income differential. Like Hurd (1987, 1989) and Jürges (2001), we use a dummy indicating if a household has one or more children in order to proxy for altruistic and strategic motives. The questionnaire also asks the households head if his family is very important to his sense of well-being and personal satisfaction. However, it is difficult to differentiate altruistic from strategic motives, since the survey does not ask for the intention of households' bequests.

\subsection{Empirical results}

Age profiles for life insurance ownership rates in the GDR are depicted in figure 2. Note that age and cohort effects cannot be separately identified, as we only use a single crosssection of data in this section. Ownership rates display a hump shape that is broadly consistent with life-cycle insurance demand as derived from the model in section 2. Life insurance ownership peaks between ages 20 to 40, while in older ages households cash out their insurance policies.

Insert figure 2 about here.

Descriptive evidence for the presence of bequest motives in GDR life-insurance demand is presented in table 6. Insurance ownership is clearly higher among married couples, households with children, households with higher labor incomes, civil servants, and house owners. Education and wealth seem to play a minor role. The descriptive evidence is hard to reconcile with the notion of intra-household reallocation motives. While ownership rates are higher for households with lager income differences, the contrary holds if the partner is not participating in the labor force.

Insert table 6 about here.

We estimate probit models for the ownership probability in 1990. Table 7 reports average marginal effects for continuous and dummy variables. We do not report separate average partial effects for the hump shaped effects of age and income on the ownership decision. 
All specifications provide robust evidence for the presence of bequest motives among households with children. ${ }^{14}$ On average, households with children are 7 percentage points more likely to own life insurance. Column (5) also controls for the attitudes of investors. Only investors for whom family is very important show a significantly higher participation probability of around seven percentage points. No significant correlation arises between insurance demand and attitudes such as security-consciousness, importance of social security, or self-assessed health status. In the specification reported in column (6), we also include indicators of leisure activities which may reflect social interaction effects (Hong, Kubik, and Stein, 2004). However, these indicators are neither individually nor jointly significant.

Because many households cash out their whole life insurance policies at retirement, we test whether that fact has a significant impact on regression results. Column (7) presents estimates for a subsample of households whose head's age is less than 65 years. In this subsample, age effects are insignificant indicating that age profiles are similar among the working population. The previous findings are broadly confirmed in this smaller sample. Estimates of potential bequest motives are statistically significant and of similar size, as in the full sample. There is no indication that investors insure the labor income of the main earner.

Insert table 7 about here.

\section{Conclusions}

Whole life insurance plays an important role in household saving. In a stylized model, both tax incentives and bequest motives drive whole life-insurance demand. While a bequest motive could be satisfied by term life insurance, sheltering savings from capital income taxation is only possible with whole life policies. The empirical evidence we presented in this paper is consistent with the theoretical predictions.

\footnotetext{
${ }^{14}$ Results reported on column (4) suggest that the probability to own one or more life insurance policies does not depend on the number of children within the household.
} 
The 2000 tax reform, which halved the tax exemption limit for capital income in Germany, can be seen as a natural experiment. Underpinned with a rich dataset, it offers a rare opportunity to study the impact of increases in capital income taxation on portfolio choice. We find that the 2000 tax change induced a significant shift of portfolios towards tax-exempt assets. Demand for life insurance increased significantly among the group of households that did not pay taxes on capital returns prior to the reform. Our estimates imply that an increase in the marginal tax rate by 10 percentage points increased life insurance ownership probabilities by 3.3 percentage points. Further, the tax reform we studied increased life insurance ownership probabilities by 5.2 percentage points among the group of households affected by the reform. These result suggest that standard tax revenue estimates, which assume that current investors would stick to their asset choices if capital taxation was introduced, may be misleading. Policy makers need to account for changes in investment behavior due to tax reforms (Poterba and Verdugo, 2008).

With regard to bequest motives, we analyzed the demand for life insurance in the experimental setting of the former communist East Germany, using data from 1990, just before German unification. Because of the peculiar institutional settings in the GDR, our estimates are not diluted by tax considerations or life-cycle and precautionary savings motives. We find a significantly higher ownership probability among households with children and a high regard for the family. Life-insurance demand does not seem to depend on intra-household allocation motives. As a note of caution, our results are based on a very peculiar institutional setting. Yet in contrast to our priors, and in favor of a broader applicability of our findings, life-insurance demand in the GDR demonstrates the importance of bequest motives for life insurance purchases - despite the presence of a communist nanny state.

\section{References}

Ai, Chunrong and Edward Norton (2003): "Interaction Terms in Logit and Probit Models," Economics Letters, 80, 123-129. 
Alan, Sule and Søren Leth-Petersen (2006): "Tax Incentives and Household Portfolios: A Panel Data Analysis," CAM Working Papers 2006-13, University of Copenhagen.

Alan, Sule; Kadir Atalaya; Thomas F. Crossley and Sung-Hee Jeon (2008): "New Evidence on Taxes and Portfolio Choice," Unpublished manuscript, University of Cambridge.

Alessie, Rob; Stefan Hochguertel and Arthur van Soest (1997): "Saving Accounts versus Stocks and Bonds in Household Portfolio Allocation," Scandinavian Journal of Economics, 99, 81-97.

Agell, Jonas and Per-Anders Edin (1990): "Marginal Taxes and the Asset Portfolios of Swedish Households," Scandinavian Journal of Economics, 9, 47-64.

Athey, Susan and Guido Imbens (2006): "Identification and Inference in Nonlinear Difference-in-Difference Models," Econometrica, 74, 431-497.

Babbel, David F. and Eisaku Ohtsuka (1989): "Aspects of Optimal Multiperiod Life Insurance," Journal of Risk and Insurance, 56, 460-481.

Banks, James and Sarah Tanner (2002): "Household Portfolios in the UK," in Household Portfolios, (eds.) Luigi Guiso, Michael Haliassos, and Tullio Jappelli. MIT Press: Cambridge, 219-250.

Beck, Thorsten and Ian Webb (2003): "Economic, Demographic, and Institutional Determinants of Life Insurance Demand across Countries," The World Bank Economic Review, 17, 51-88.

Bernheim, Douglas; Andrei Shleifer and Lawrence H. Summers (1985): "The Strategic Bequest Motive," Journal of Political Economy, 93, 1045-1076.

Bernheim, Douglas (1991): "How Strong Are Bequest Motives? Evidence Based on Estimates of the Demand for Life Insurance and Annuities," Journal of Political Economy, 99, 899-927.

Browne, Mark J. and Kihong Kim (1993): “An International Analysis of Life Insurance Demand," Journal of Risk and Insurance, 60, 460-481.

Browning, Martin and Annamaria Lusardi (1996): "Household Saving: Micro Theories and Micro Facts," Journal of Economic Literature, 34, 1797-1855. 
Dabbert, Edith (1992): "Von 280 Mark zu 11830 Mark - 40 Jahre Sparen," in Im Trabi durch die Zeit - 40 Jahre Leben in der DDR, (ed.) Egon Hölder. Metzler-Poeschel: Stuttgart, 121-127.

Deutsche Bundesbank (2008): Ergebnisse der gesamtwirtschaftlichen Finanzierungsrechnung für Deutschland 1991 bis 2007, Statistische Sonderveröffentlichung 4. Deutsche Bundesbank: Frankfurt.

Dolle-Helms, Elke (1999a): "Geschäft des Lebens," Die Zeit, 36, 28.

Dolle-Helms, Elke (1999b): "Voreilig abgeschlossen?," Die Zeit, 52, 32.

Fischer, Stanley (1973): "A Life Cycle Model of Life Insurance Purchases," International Economic Review, 14, 132-152.

Fuchs-Schündeln, Nicola and Matthias Schündeln (2005): "Precautionary Savings and Self-Selection: Evidence from the German Reunification Experiment," Quarterly Journal of Economics, 120, 1085-1120.

Gandolfi, Anna Sachko and Laurence Miners (1996): "Gender-Based Differences in Life Insurance Ownership," The Journal of Risk and Insurance, 63, 683-693.

Gesamtverband der Deutschen Versicherungswirtschaft (2008): Geschäftsentwicklung 200\%. Die deutsche Lebensversicherung in Zahlen. GDV: Berlin.

Haisken-DeNew, John P. and Markus Hahn (2006): "PanelWhiz: A Flexible Modularized Stata Interface for Accessing Large Scale Panel Data Sets," mimeo, (http:// www.PanelWhiz.eu).

Hong, Harrison; Jeffrey D. Kubik and Jeremy C. Stein (2004): "Social Interaction and Stock-Market Participation," Journal of Finance, 59, 137-163.

Hurd, Michael D. (1987): "Savings of the Elderly and Desired Bequests," American Economic Review, 77, 298-312.

Hurd, Michael D. (1989): "Mortality Risk and Bequests," Econometrica, 57, 779-813.

Jappelli, Tullio and Luigi Pistaferri (2003): "Tax Incentives and the Demand for Life Insurance," Journal of Public Economics, 87, 1779-1799. 
Jappelli, Tullio and Luigi Pistaferri (2007): "Do People Respond to Tax Incentives? An Analysis of the Italian Reform of the Deductibility of Home Mortgage Interest," European Economic Review, 51, 247-273.

Jürges, Hendrik (2001): "Do Germans Save to Leave an Estate? An Examination of the Bequest Motive," The Scandinavian Journal of Economics, 103, 391-414.

King, Mervyn A. and Jonathan I. Leape (1998): "Wealth and Portfolio Composition: Theory and Evidence," Journal of Public Economics, 69, 155-193.

Kopczuk, Wojciech and Joseph P. Lupton (2007): "To Leave or Not to Leave: The Distribution of Bequest Motives," Review of Economic Studies, 74, 207-235.

Laitner, John and Thomas Juster (1996): "New Evidence on Altruism: A Study of TIAACREF Retirees," American Economic Review, 86, 893-908.

Lewis, Frank D. (1989): "Dependents and the Demand for Life Insurance," American Economic Review, 79, 452-467.

Manzel, Karl-Heinz (1992): "Von der Wohnlaube zum Wohnblock - Ziel der 'registrierten Antragstellung,", in Im Trabi durch die Zeit - 40 Jahre Leben in der DDR, (ed.) Egon Hölder. Metzler-Poeschel: Stuttgart, 251-264.

Marggraf, Hans-Jörg (1992): “Von der 'Demokratisierung der deutschen Schule' zum sozialistischen Bildungssystem - der Weg vom Kindergarten zum Beruf," in Im Trabi durch die Zeit - 40 Jahre Leben in der DDR, (ed.) Egon Hölder. MetzlerPoeschel: Stuttgart, 49-66.

Poterba, James M. (2002): "Taxation and Portfolio Structure: Issues and Implications," in Household Portfolios, (eds.) Luigi Guiso, Michael Haliassos, and Tullio Jappelli. MIT Press: Cambridge, 103-142.

Poterba, James M. and Andrew A. Samwick (2003): "Taxation and Household Portfolio Composition: U.S. Evidence from the 1980s and 1990s," Journal of Public Economics, 87, 5-38.

Poterba, James and Arzuro Ramirez Verdugo (2008): "Portfolio Substitution and the Revenue Cost of Exempting State and Local Government Interest Payments from Federal Income Tax," NBER Working Paper No. 14439. 
Puhani, Patrick A. (2008): "The Treatment Effect, the Cross Difference, and the Interaction Term in Nonlinear "Difference in Differences" Models," IZA Discussion Paper No. 3478 .

Saretzki, Hans-Ulrich and Ursula Kohn (1992): "Vom gewerkschaftlich organisierten Urlaub zum begrenzten Tourismus - Reisen als Beitrag zur Lebensqualität," in Im Trabi durch die Zeit - 40 Jahre Leben in der DDR, (ed.) Egon Hölder. MetzlerPoeschel: Stuttgart, 329-341.

Scholz, John K. (1994): "Portfolio Choice and Tax Progressivity: Evidence from the Surveys of Consumer Finances," in Tax Progressivity and Income Inequality, (ed.) Joel Slemrod. New York: Cambridge University Press, 219-267.

Schulze, Siegfried (1970): Versicherungsrecht. Staatsverlag der DDR: Berlin.

Schwarze, Johannes (1995): "Simulating German Income and Scoail Security Tax Payments Using the GSOEP," Cross-National Studies in Aging Program, Project Paper No. 19.

Schwarzer, Oskar (1999): Sozialistische Zentralplan-Wirtschaft in der SBZ/DDR. Ergebnisse eines ordnugspolitischen Experiments (1945-1989). Franz Steiner Verlag: Stuttgart.

Sommer, Matthias (2007): "Savings motives and the effectiveness of tax incentives - an analysis based on the demand for life-insurance in Germany," MEA Discussion Paper 99-28, University of Mannheim.

Tomes, Nigel (1981): "The Family, Inheritance, and the Intergenerational Transmission of Inequality," Journal of Political Economy, 89, 928-958.

Walliser, Jan and Joachim Winter (1999): "Tax Incentives, Bequest Motives, and the Demand for Life Insurance: Evidence from Germany," Discussion Paper No. 9928, Sonderforschungsbereich 504, University of Mannheim.

Wolle, Stefan (1999): Die heile Welt der Diktatur. Alltag und Herrschaft in der DDR 1971-1989. Bundeszentrale für politische Bildung: Bonn.

Yaari, Menahem E. (1965): "Uncertain Lifetime, Life Insurance and the Theory of the Consumer," Review of Economic Studies, 32, 137-150. 


\section{Technical appendix}

The solution for first period consumption $c_{0}$ can be derived as follows:

$$
\begin{aligned}
c_{0}= & {\left[\left(1+\frac{1}{R}\left(R \eta_{3}\right)^{\frac{1}{\gamma}}\right)\left[\frac{\left(R^{C}-R \alpha\right)^{2} \frac{\pi_{1} \pi_{2}}{1+\delta}}{\left(1-Z_{0} R\right)\left(1-Z_{1} R\right)}\right]^{\frac{1}{\gamma}}+\right.} \\
& \left(\frac{R^{C}-\alpha R}{1-Z_{1} R} Z_{1}-\alpha\right)\left(\frac{\left(1-\pi_{2}\right) \eta_{2} \frac{\pi_{1}}{1+\delta}\left(R^{C}-\alpha R\right)^{2}}{\left(Z_{1} R^{C}-\alpha\right)\left(1-Z_{0} R\right)}\right)^{\frac{1}{\gamma}}+ \\
& \left(\frac{R^{C}-\alpha R}{1-Z_{1} R}\right)\left(\left(\frac{\left(R^{C}-\alpha R\right) \frac{\pi_{1}}{1+\delta}}{1-Z_{0} R}\right)^{\frac{1}{\gamma}}+\right. \\
& \left.\left(\frac{R^{C}-\alpha R}{1-Z_{1} R} Z_{1}-\alpha\right)\left(\frac{\left(1-\pi_{1}\right) \eta_{1}\left(R^{C}-\alpha R\right)}{Z_{0} R^{C}-\alpha}\right)^{\frac{1}{\gamma}}\right)+ \\
& \left.\frac{\left(R^{C}-\alpha R\right)^{2}}{\left(1-Z_{0} R\right)\left(1-Z_{1} R\right)}\right]^{-1} \times \\
& {\left[\frac{\left(R^{C}-\alpha R\right)^{2}}{\left(1-Z_{0} R\right)\left(1-Z_{1} R\right)} w_{0}\left(1-\tau^{S}\right)+\right.} \\
& \left.\frac{R^{C}-\alpha R}{1-Z_{1} R} w_{1}\left(1-\tau^{S}\right)+\tau^{S}\left(w_{0} G^{2}+w_{1} G\right)\right]
\end{aligned}
$$

The solution for $c_{0}$ in combination with equations (6), (7) and (8) immediately implies values for $c_{1}, c_{2}, b_{1}, b_{2}, b_{3}$ and thus, by applying the budget constraints, also for $L_{1}$ and $L_{2}$. 


\section{Figures and tables}

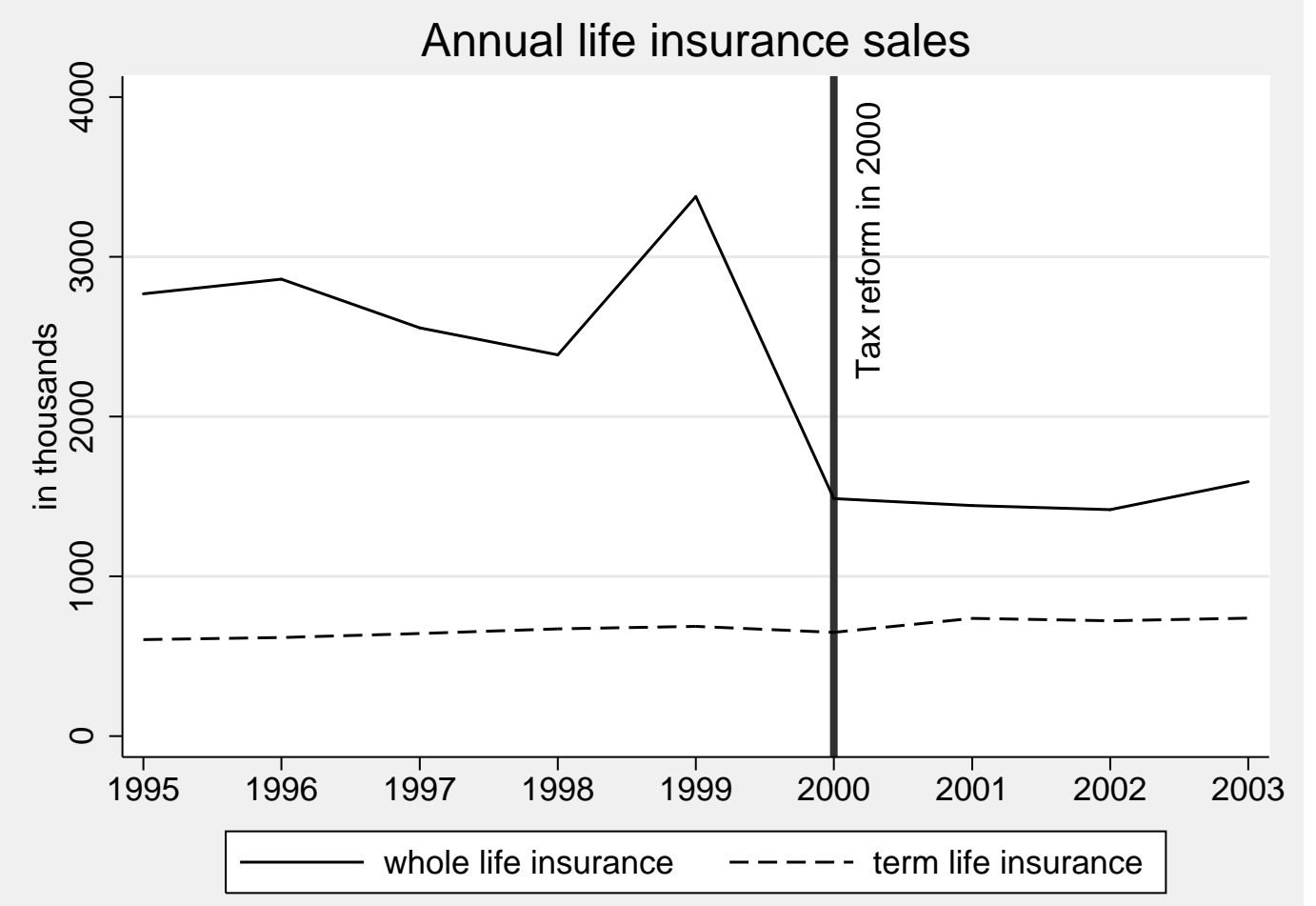

Figure 1: The graph depicts sales of new life insurance contracts in 2007 in Germany. Source: Gesamtverband der Deutschen Versicherungswirtschaft (2008). 


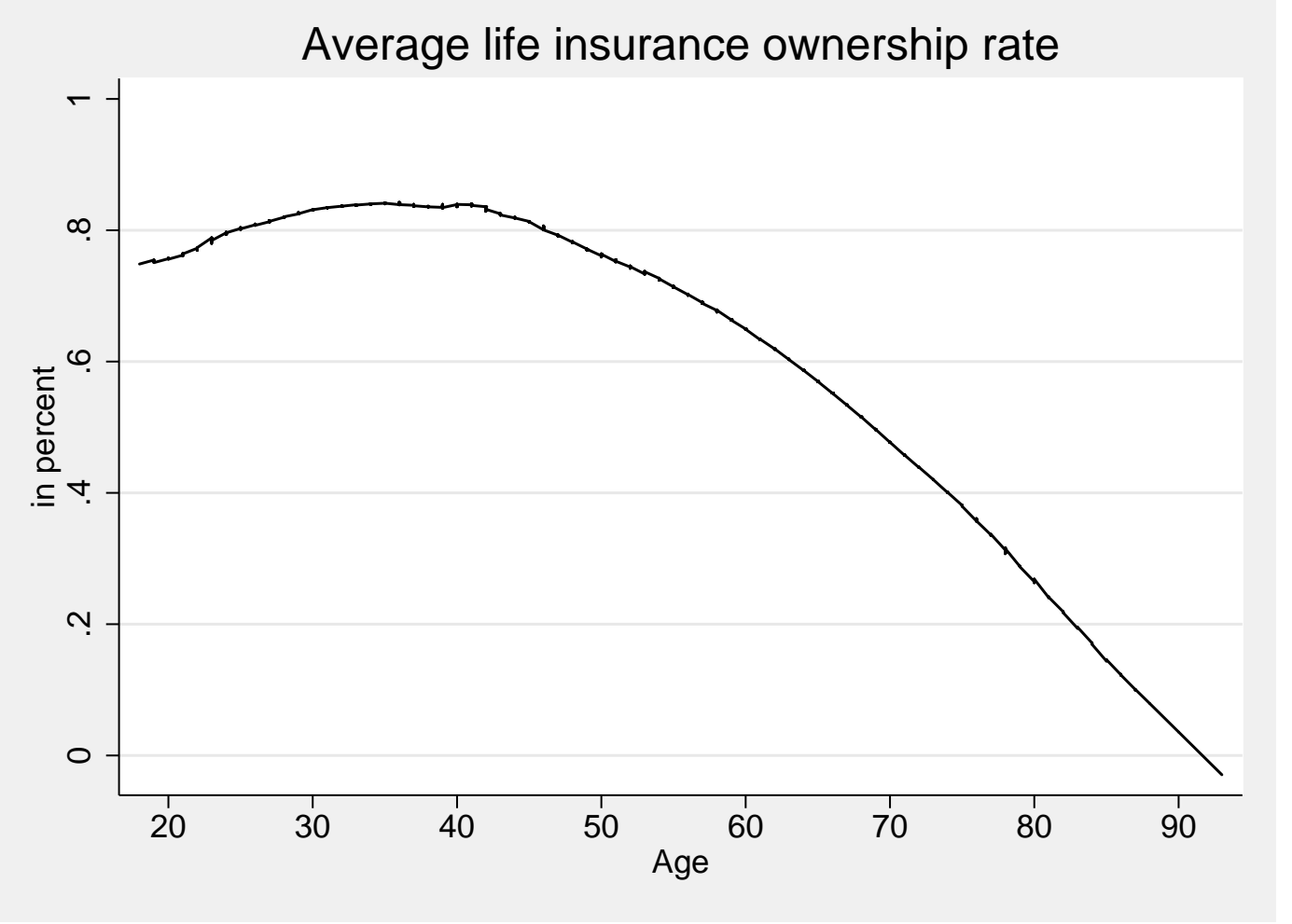

Figure 2: The graph depicts the (smoothed) average life insurance ownership rate in East Germany, 1990. Source: GSOEP. 
Table 1: Tax exemption limits on capital income

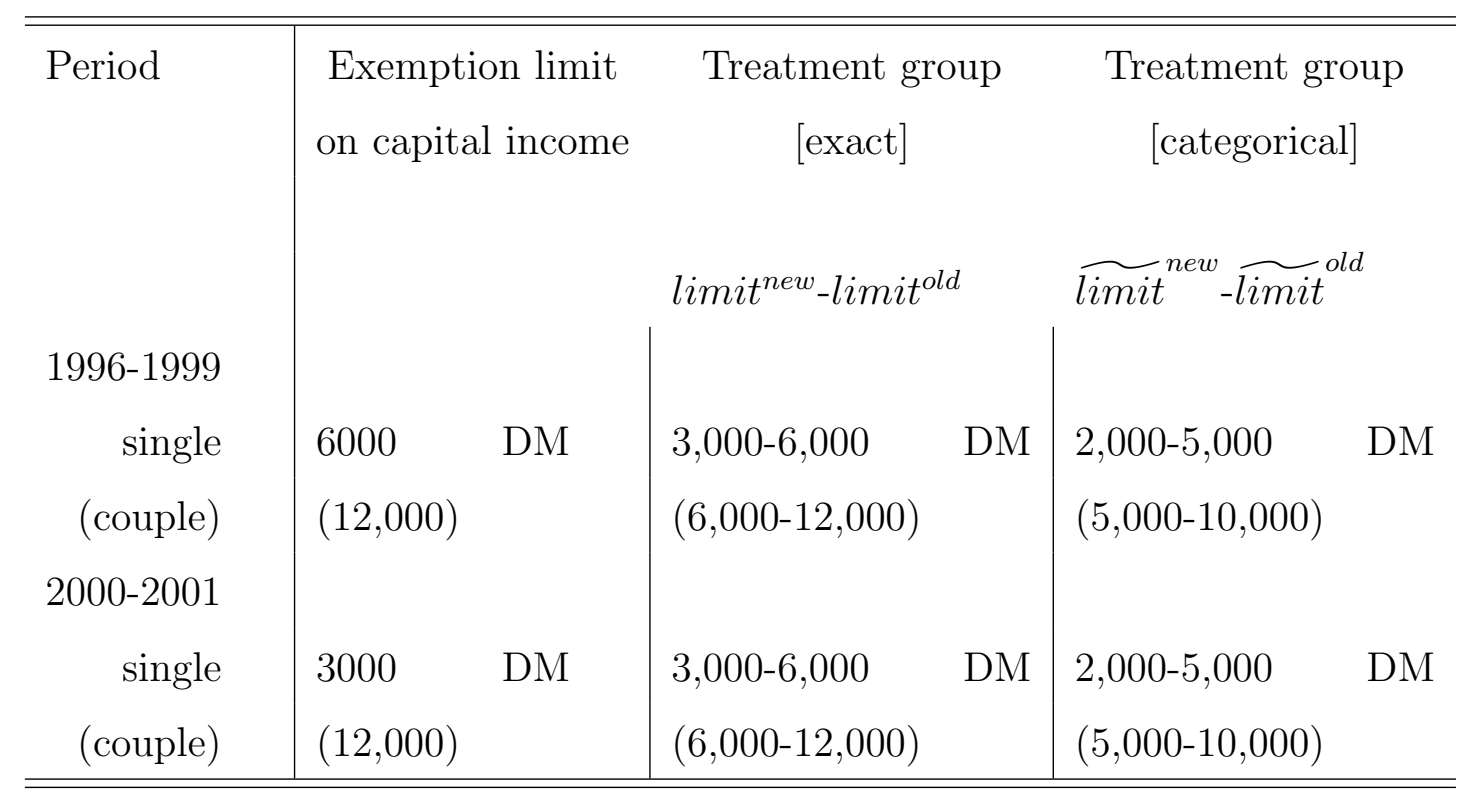

Note: The table reports the development of tax exemption limits on capital income in Germany for singles (married couples). The thresholds for the old and new exemption limits, limit ${ }^{\text {old }}$ and limit $^{\text {new }}$, define the upper and lower bounds of the treatment group and are either assigned by exact or categorical (indicated by tilde) interest and dividend returns. 
Table 2: Tax incentives - average ownership rates 1996-2001

\begin{tabular}{|c|c|c|c|c|c|c|}
\hline & 1996 & 1997 & 1998 & 1999 & 2000 & 2001 \\
\hline Full sample & 54.72 & 55.79 & 54.56 & 55.29 & 54.67 & 52.38 \\
\hline$N$ & 6,594 & 6,383 & 7,159 & 6,980 & 11,662 & 11,193 \\
\hline$I N C^{C A P}<$ limit $^{\text {new }}$ & 54.28 & 55.52 & 54.20 & 54.48 & 54.09 & 51.85 \\
\hline$N$ & 6,278 & 6,092 & 6,816 & 6,533 & 10,959 & 10,703 \\
\hline$I N C^{C A P}>$ limit $^{\text {old }}$ & 64.84 & 67.71 & 60.36 & 62.58 & 63.11 & 62.29 \\
\hline$N$ & 91 & 96 & 111 & 163 & 225 & 175 \\
\hline limit $^{\text {new }}<I N C^{C A P}<$ limit $^{\text {old }}$ & 62.67 & 58.46 & 62.50 & 69.72 & 64.02 & 65.08 \\
\hline$N$ & 225 & 195 & 232 & 284 & 478 & 315 \\
\hline
\end{tabular}

Note: The table reports average ownership rates of life insurance policies for different subpopulations. INC $C^{C A P}$ denotes total capital income. 
Table 3: Tax incentives - Difference-in-Differences

\begin{tabular}{lcccc}
\hline \hline & treated & non-treated & $\begin{array}{c}\text { Difference } \\
\text { between } \\
\text { groups }\end{array}$ & $\mathrm{N}$ \\
\hline Effect of the tax reform. & & & & \\
$\mathrm{N}$ & 1,729 & 47,961 & & 49,690 \\
After the reform (1999-2001) & 0.658 & 0.536 & 0.123 & 29,554 \\
& $(0.014)$ & $(0.003)$ & $(0.015)$ & \\
Before the reform (1996-1999) & 0.613 & 0.548 & 0.066 & 20,136 \\
& $(0.019)$ & $(0.004)$ & $(0.020)$ & \\
Difference within groups & 0.045 & -0.012 & $\mathbf{0 . 0 5 7}$ & \\
& $(0.024)$ & $(0.005)$ & $\mathbf{( 0 . 0 0 0 )}$ & \\
Effect of the tax reform, INCCAP $>$ limit & & & \\
N & 1,729 & 861 & & 1,640 \\
After the reform (1999-2001) & 0.658 & 0.627 & 0.031 & \\
& $(0.014)$ & $(0.020)$ & $(0.025)$ & \\
Before the reform (1996-1999) & 0.613 & 0.641 & -0.028 & \\
& $(0.028)$ & $(0.019)$ & $(0.034)$ & \\
Difference within groups & 0.045 & -0.014 & $\mathbf{0 . 0 5 9}$ & $(\mathbf{0 . 0 0 1 )}$ \\
& $(0.024)$ & $(0.035)$ & & \\
\hline \hline
\end{tabular}

Note: The upper panel reports average ownership rates of life insurance policies for the years 1996-2001. The bottom panel reports averages for all households with a capital income $I N C^{C A P}>$ limit $^{\text {new }}$. The difference-in-difference estimate is reported in bold face in the bottom right cell of each panel. Standard errors are reported in parentheses. 
Table 4: Tax incentives - summary statistics

\begin{tabular}{|c|c|c|c|}
\hline & & full sample & $\begin{array}{l}I N C^{C A P}> \\
\text { limit }^{\text {new }}\end{array}$ \\
\hline marginal tax rate & & 0.249 & 0.338 \\
\hline woman & $\mathrm{D}$ & 0.376 & 0.277 \\
\hline age & & 48.87 & 52.39 \\
\hline children & $\mathrm{D}$ & 0.340 & 0.218 \\
\hline married & $\mathrm{D}$ & 0.829 & 0.730 \\
\hline 10 years schooling & $\mathrm{D}$ & 0.280 & 0.250 \\
\hline 13 years schooling & $\mathrm{D}$ & 0.200 & 0.424 \\
\hline college & $\mathrm{D}$ & 0.086 & 0.132 \\
\hline university & $\mathrm{D}$ & 0.100 & 0.240 \\
\hline self-employed & $\mathrm{D}$ & 0.057 & 0.136 \\
\hline civil servant & $\mathrm{D}$ & 0.045 & 0.070 \\
\hline retired & $\mathrm{D}$ & 0.283 & 0.320 \\
\hline unemployed & $\mathrm{D}$ & 0.078 & 0.035 \\
\hline Hhold income decile 1 & $\mathrm{D}$ & 0.099 & 0.026 \\
\hline Hhold income decile 2 & $\mathrm{D}$ & 0.103 & 0.039 \\
\hline Hhold income decile 3 & $\mathrm{D}$ & 0.097 & 0.054 \\
\hline Hhold income decile 4 & $\mathrm{D}$ & 0.101 & 0.070 \\
\hline Hhold income decile 6 & $\mathrm{D}$ & 0.111 & 0.100 \\
\hline Hhold income decile 7 & $\mathrm{D}$ & 0.097 & 0.078 \\
\hline Hhold income decile 8 & $\mathrm{D}$ & 0.097 & 0.111 \\
\hline Hhold income decile 9 & $\mathrm{D}$ & 0.099 & 0.174 \\
\hline Hhold income decile 10 & $\mathrm{D}$ & 0.094 & 0.284 \\
\hline owns house & $\mathrm{D}$ & 0.405 & 0.632 \\
\hline returns $<2,000 \mathrm{DM}$ & $\mathrm{D}$ & 0.231 & \\
\hline returns $<5,000 \mathrm{DM}$ & $\mathrm{D}$ & 0.084 & \\
\hline returns $<10,000 \mathrm{DM}$ & $\mathrm{D}$ & 0.033 & \\
\hline returns $>10,000 \mathrm{DM}$ & $\mathrm{D}$ & 0.016 & \\
\hline $\mathrm{N}$ & & 44,540 & 2,419 \\
\hline Sample years & & $1996-2001$ & $1996-2001$ \\
\hline
\end{tabular}

Note: The samples are from the GSOEP. Demographic variables refer to the household head. Dummy variables are marked by $\mathrm{D}$. 
Table 5: Tax incentives - average marginal effects

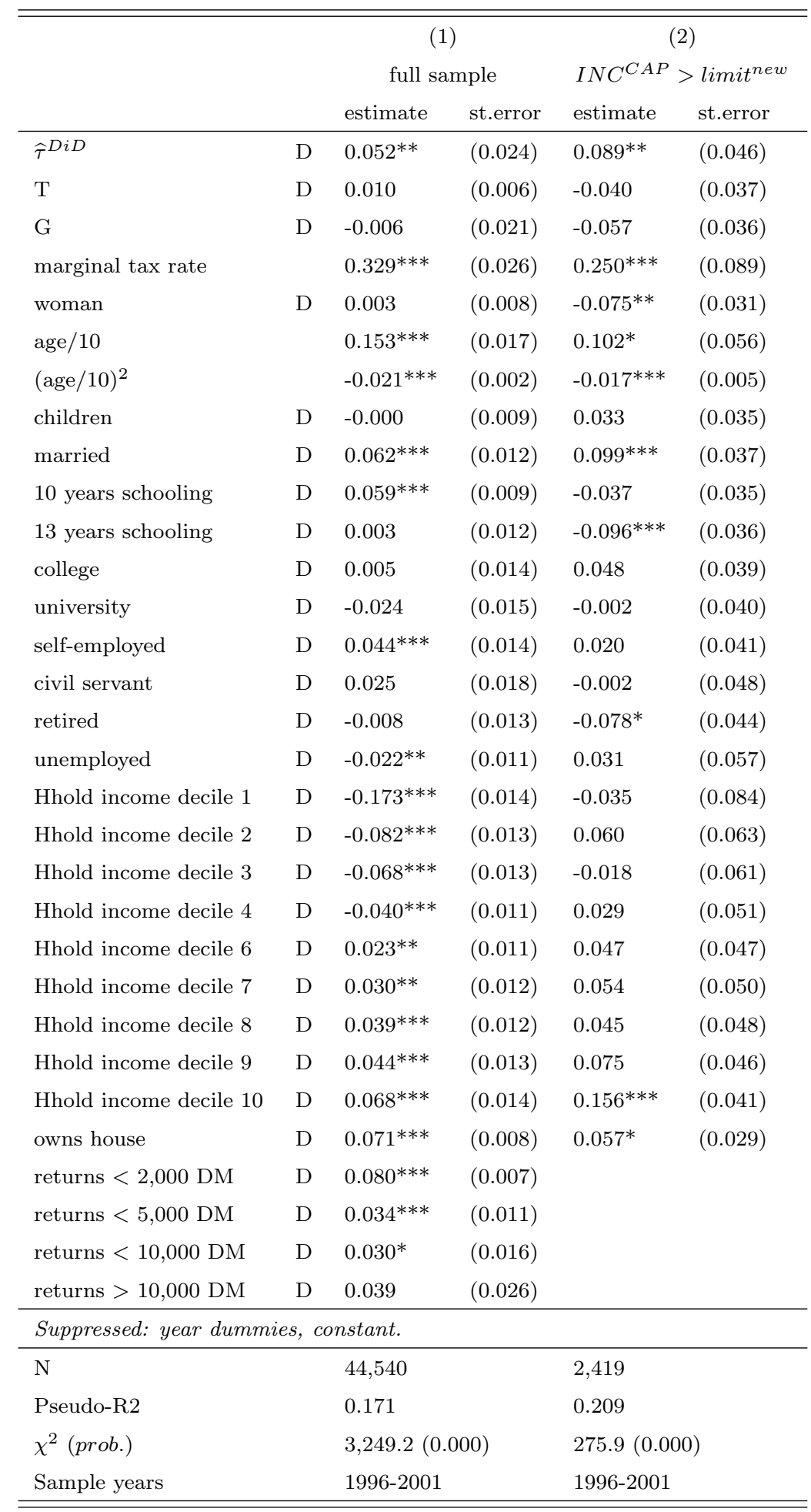

D indicates dummy variables. Average marginal effects are reported. Robust and clustered standard errors are reported in parentheses. ${ }^{* * *},{ }^{* *}, *$ indicate significance at the 0.01, 0.05, 0.1 level. 
Table 6: Bequest motives - summary statistics

\begin{tabular}{|c|c|c|c|c|c|c|}
\hline & \multicolumn{2}{|c|}{ subsamples } & \multicolumn{4}{|c|}{ All observations } \\
\hline & owner & non-owner & & & & \\
\hline & Mean & Mean & Mean & Std. Dev. & Min & Max \\
\hline age & 43.2 & 53.5 & 46.1 & 15.9 & 17 & 93 \\
\hline woman & 0.50 & 0.55 & 0.51 & 0.50 & 0 & 1 \\
\hline married & 0.77 & 0.53 & 0.70 & 0.46 & 0 & 1 \\
\hline 10 years schooling & 0.48 & 0.34 & 0.44 & 0.50 & 0 & 1 \\
\hline 13 years schooling & 0.15 & 0.13 & 0.14 & 0.35 & 0 & 1 \\
\hline master craftsman & 0.08 & 0.07 & 0.08 & 0.27 & 0 & 1 \\
\hline college & 0.20 & 0.17 & 0.19 & 0.39 & 0 & 1 \\
\hline university & 0.10 & 0.10 & 0.10 & 0.30 & 0 & 1 \\
\hline returns $<200$ Mark & 0.24 & 0.21 & 0.23 & 0.42 & 0 & 1 \\
\hline returns $<500$ Mark & 0.24 & 0.23 & 0.24 & 0.43 & 0 & 1 \\
\hline returns $<1,000$ Mark & 0.13 & 0.09 & 0.12 & 0.33 & 0 & 1 \\
\hline returns $>1,000$ Mark & 0.06 & 0.08 & 0.06 & 0.24 & 0 & 1 \\
\hline Hhold income/10,000 & 0.18 & 0.13 & 0.17 & 0.07 & 0.03 & 0.51 \\
\hline partner no job & 0.09 & 0.16 & 0.11 & 0.32 & 0 & 1 \\
\hline partner income diff./1,000 & 0.39 & 0.26 & 0.35 & 0.43 & 0 & 3.63 \\
\hline retired & 0.10 & 0.38 & 0.17 & 0.38 & 0 & 1 \\
\hline self-employed & 0.03 & 0.02 & 0.02 & 0.15 & 0 & 1 \\
\hline civil servant & 0.31 & 0.19 & 0.27 & 0.45 & 0 & 1 \\
\hline owns house & 0.30 & 0.24 & 0.29 & 0.45 & 0 & 1 \\
\hline owns weekend house & 0.17 & 0.11 & 0.15 & 0.36 & 0 & 1 \\
\hline no car & 0.36 & 0.56 & 0.42 & 0.49 & 0 & 1 \\
\hline motorbike & 0.42 & 0.23 & 0.37 & 0.48 & 0 & 1 \\
\hline children & 0.54 & 0.28 & 0.47 & 0.50 & 0 & 1 \\
\hline one child & 0.25 & 0.14 & 0.22 & 0.42 & 0 & 1 \\
\hline two children & 0.24 & 0.12 & 0.20 & 0.40 & 0 & 1 \\
\hline three children + & 0.05 & 0.02 & 0.04 & 0.20 & 0 & 1 \\
\hline family very important & 0.89 & 0.74 & 0.85 & 0.36 & 0 & 1 \\
\hline unsatisfied social benefits & 0.56 & 0.54 & 0.55 & 0.50 & 0 & 1 \\
\hline security consciousness & 8.83 & 8.75 & 8.81 & 1.83 & 0 & 10 \\
\hline Health satisfaction & 6.80 & 6.25 & 6.65 & 2.64 & 0 & 10 \\
\hline classical concerts, theatre & 0.13 & 0.11 & 0.12 & 0.32 & 0 & 1 \\
\hline pop concerts, movies, discos & 0.13 & 0.16 & 0.15 & 0.36 & 0 & 1 \\
\hline active sports & 0.14 & 0.15 & 0.14 & 0.35 & 0 & 1 \\
\hline meet friends, neighbors & 0.58 & 0.66 & 0.64 & 0.48 & 0 & 1 \\
\hline help friends, neighbors & 0.40 & 0.49 & 0.46 & 0.50 & 0 & 1 \\
\hline attend church services & 0.11 & 0.07 & 0.08 & 0.28 & 0 & 1 \\
\hline $\mathrm{N}$ & 1487 & 562 & 2049 & & & \\
\hline
\end{tabular}

Note: The sample is the 1990 GSOEP for East Germany. Demographic variables refer to the household head. 
Table 7: Bequest motives - average marginal effects

\begin{tabular}{|c|c|c|c|c|c|c|}
\hline & & (3) & $(4)$ & $(5)$ & (6) & $\begin{array}{l}(7) \\
\text { only }<65\end{array}$ \\
\hline age/10 & & $\begin{array}{l}0.165^{* * *} \\
(0.041)\end{array}$ & $\begin{array}{l}0.165^{* * *} \\
(0.041)\end{array}$ & $\begin{array}{l}0.168^{* * *} \\
(0.042)\end{array}$ & $\begin{array}{l}0.167^{* * *} \\
(0.042)\end{array}$ & $\begin{array}{l}0.048 \\
(0.069)\end{array}$ \\
\hline$(\text { age } / 10)^{2}$ & & $\begin{array}{l}-0.019 * * * \\
(0.004)\end{array}$ & $\begin{array}{l}-0.019^{* * *} \\
(0.004)\end{array}$ & $\begin{array}{l}-0.019^{* * *} \\
(0.004)\end{array}$ & $\begin{array}{l}-0.019^{* * *} \\
(0.004)\end{array}$ & $\begin{array}{l}-0.004 \\
(0.008)\end{array}$ \\
\hline woman & $\mathrm{D}$ & $\begin{array}{l}0.041^{* *} \\
(0.020)\end{array}$ & $\begin{array}{l}0.041^{* *} \\
(0.020)\end{array}$ & $\begin{array}{l}0.037^{*} \\
(0.020)\end{array}$ & $\begin{array}{l}0.045^{* *} \\
(0.020)\end{array}$ & $\begin{array}{l}0.031 \\
(0.020)\end{array}$ \\
\hline married & $\mathrm{D}$ & $\begin{array}{l}0.024 \\
(0.028)\end{array}$ & $\begin{array}{l}0.025 \\
(0.028)\end{array}$ & $\begin{array}{l}0.013 \\
(0.028)\end{array}$ & $\begin{array}{l}0.025 \\
(0.028)\end{array}$ & $\begin{array}{l}0.010 \\
(0.028)\end{array}$ \\
\hline 10 years schooling & $\mathrm{D}$ & $\begin{array}{l}-0.006 \\
(0.026)\end{array}$ & $\begin{array}{l}-0.006 \\
(0.026)\end{array}$ & $\begin{array}{l}-0.001 \\
(0.027)\end{array}$ & $\begin{array}{l}-0.006 \\
(0.026)\end{array}$ & $\begin{array}{l}-0.003 \\
(0.028)\end{array}$ \\
\hline 13 years schooling & $\mathrm{D}$ & $\begin{array}{l}-0.000 \\
(0.043)\end{array}$ & $\begin{array}{l}-0.000 \\
(0.043)\end{array}$ & $\begin{array}{l}0.002 \\
(0.043)\end{array}$ & $\begin{array}{l}0.007 \\
(0.043)\end{array}$ & $\begin{array}{l}-0.007 \\
(0.044)\end{array}$ \\
\hline master craftsman & $\mathrm{D}$ & $\begin{array}{l}0.034 \\
(0.036)\end{array}$ & $\begin{array}{l}0.034 \\
(0.036)\end{array}$ & $\begin{array}{l}0.027 \\
(0.037)\end{array}$ & $\begin{array}{l}0.036 \\
(0.036)\end{array}$ & $\begin{array}{l}-0.003 \\
(0.040)\end{array}$ \\
\hline college & $\mathrm{D}$ & $\begin{array}{l}-0.046^{*} \\
(0.027)\end{array}$ & $\begin{array}{l}-0.046^{*} \\
(0.027)\end{array}$ & $\begin{array}{l}-0.049^{*} \\
(0.027)\end{array}$ & $\begin{array}{l}-0.042 \\
(0.027)\end{array}$ & $\begin{array}{l}-0.041 \\
(0.028)\end{array}$ \\
\hline university & $\mathrm{D}$ & $\begin{array}{l}-0.101^{* *} \\
(0.049)\end{array}$ & $\begin{array}{l}-0.100^{* *} \\
(0.049)\end{array}$ & $\begin{array}{l}-0.095^{*} \\
(0.049)\end{array}$ & $\begin{array}{l}-0.096^{*} \\
(0.049)\end{array}$ & $\begin{array}{l}-0.088^{*} \\
(0.051)\end{array}$ \\
\hline returns < 200 Mark & $\mathrm{D}$ & $\begin{array}{l}0.021 \\
(0.024)\end{array}$ & $\begin{array}{l}0.021 \\
(0.024)\end{array}$ & $\begin{array}{l}0.023 \\
(0.024)\end{array}$ & $\begin{array}{l}0.021 \\
(0.024)\end{array}$ & $\begin{array}{l}0.012 \\
(0.025)\end{array}$ \\
\hline returns < 500 Mark & $\mathrm{D}$ & $\begin{array}{l}0.016 \\
(0.024)\end{array}$ & $\begin{array}{l}0.016 \\
(0.024)\end{array}$ & $\begin{array}{l}0.019 \\
(0.024)\end{array}$ & $\begin{array}{l}0.019 \\
(0.024)\end{array}$ & $\begin{array}{l}0.017 \\
(0.025)\end{array}$ \\
\hline returns < 500 Mark & $\mathrm{D}$ & $\begin{array}{l}0.070^{* *} \\
(0.029)\end{array}$ & $\begin{array}{l}0.069 * * \\
(0.029)\end{array}$ & $\begin{array}{l}0.071^{* *} \\
(0.029)\end{array}$ & $\begin{array}{l}0.072^{* *} \\
(0.029)\end{array}$ & $\begin{array}{l}0.063^{* *} \\
(0.028)\end{array}$ \\
\hline returns $>1,000$ Mark & $\mathrm{D}$ & $\begin{array}{l}-0.075 \\
(0.046)\end{array}$ & $\begin{array}{l}-0.075^{*} \\
(0.046)\end{array}$ & $\begin{array}{c}-0.078^{*} \\
(0.046)\end{array}$ & $\begin{array}{l}-0.069 \\
(0.046)\end{array}$ & $\begin{array}{l}-0.099 * * \\
(0.050)\end{array}$ \\
\hline Hhold income/10,000 & $\mathrm{D}$ & $\begin{array}{l}2.102^{* * *} \\
(0.532)\end{array}$ & $\begin{array}{l}2.106^{* * *} \\
(0.533)\end{array}$ & $\begin{array}{l}1.776^{* * *} \\
(0.539)\end{array}$ & $\begin{array}{l}2.115^{* * *} \\
(0.530)\end{array}$ & $\begin{array}{l}2.054^{* * *} \\
(0.564)\end{array}$ \\
\hline$(\text { Hhold income } / 10,000)^{2}$ & & $\begin{array}{l}-3.919^{* * *} \\
(1.249)\end{array}$ & $\begin{array}{l}-3.927^{* * *} \\
(1.250)\end{array}$ & $\begin{array}{l}-3.119 * * \\
(1.268)\end{array}$ & $\begin{array}{l}-3.938^{* * *} \\
(1.241)\end{array}$ & $\begin{array}{l}-3.613^{* * *} \\
(1.299)\end{array}$ \\
\hline partner no job & & $\begin{array}{l}-0.006 \\
(0.031)\end{array}$ & $\begin{array}{l}-0.007 \\
(0.031)\end{array}$ & $\begin{array}{l}-0.006 \\
(0.032)\end{array}$ & $\begin{array}{l}-0.005 \\
(0.031)\end{array}$ & $\begin{array}{l}0.005 \\
(0.039)\end{array}$ \\
\hline partner income diff./1000 & $\mathrm{D}$ & $\begin{array}{l}0.022 \\
(0.024)\end{array}$ & $\begin{array}{l}0.022 \\
(0.024)\end{array}$ & $\begin{array}{l}0.022 \\
(0.024)\end{array}$ & $\begin{array}{l}0.022 \\
(0.024)\end{array}$ & $\begin{array}{l}0.021 \\
(0.024)\end{array}$ \\
\hline retired & & $\begin{array}{l}-0.045 \\
(0.046)\end{array}$ & $\begin{array}{l}-0.044 \\
(0.046)\end{array}$ & $\begin{array}{l}-0.053 \\
(0.047)\end{array}$ & $\begin{array}{l}-0.053 \\
(0.046)\end{array}$ & $\begin{array}{l}0.036 \\
(0.056)\end{array}$ \\
\hline self-employed & $\mathrm{D}$ & $\begin{array}{l}0.023 \\
(0.059)\end{array}$ & $\begin{array}{l}0.023 \\
(0.059)\end{array}$ & $\begin{array}{l}0.018 \\
(0.059)\end{array}$ & $\begin{array}{l}0.028 \\
(0.058)\end{array}$ & $\begin{array}{l}0.026 \\
(0.056)\end{array}$ \\
\hline civil servant & $\mathrm{D}$ & $\begin{array}{l}0.027 \\
(0.022)\end{array}$ & $\begin{array}{l}0.026 \\
(0.022)\end{array}$ & $\begin{array}{l}0.025 \\
(0.022)\end{array}$ & $\begin{array}{l}0.027 \\
(0.022)\end{array}$ & $\begin{array}{l}0.017 \\
(0.021)\end{array}$ \\
\hline
\end{tabular}


... Table 7 continued ...
(3)
(4)
(5)
$(6)$
(7)

\begin{tabular}{|c|c|c|c|c|c|c|}
\hline & & & & & & only $<65$ \\
\hline \multirow[t]{2}{*}{ owns house } & $\mathrm{D}$ & 0.016 & 0.016 & 0.015 & 0.013 & 0.024 \\
\hline & & $(0.022)$ & $(0.022)$ & $(0.022)$ & $(0.022)$ & $(0.023)$ \\
\hline \multirow[t]{2}{*}{ owns weekend house } & $\mathrm{D}$ & 0.023 & 0.023 & 0.023 & 0.021 & 0.037 \\
\hline & & $(0.026)$ & $(0.026)$ & $(0.026)$ & $(0.026)$ & $(0.025)$ \\
\hline \multirow[t]{2}{*}{ no car } & $\mathrm{D}$ & 0.012 & 0.011 & 0.009 & 0.011 & 0.007 \\
\hline & & $(0.022)$ & $(0.022)$ & $(0.022)$ & $(0.022)$ & $(0.022)$ \\
\hline \multirow[t]{2}{*}{ motorbike } & $\mathrm{D}$ & $0.058^{* * *}$ & $0.058^{* * *}$ & $0.059^{* * *}$ & $0.057^{* * *}$ & $0.056^{* * *}$ \\
\hline & & $(0.021)$ & $(0.021)$ & $(0.021)$ & $(0.021)$ & $(0.021)$ \\
\hline \multirow[t]{2}{*}{ children } & $\mathrm{D}$ & $0.070^{* * *}$ & & $0.063^{* *}$ & $0.070^{* * *}$ & $0.071^{* * *}$ \\
\hline & & $(0.025)$ & & $(0.026)$ & $(0.026)$ & $(0.026)$ \\
\hline \multirow[t]{2}{*}{ one child } & $\mathrm{D}$ & & $0.080^{* * *}$ & & & \\
\hline & & & $(0.029)$ & & & \\
\hline \multirow[t]{2}{*}{ two children } & $\mathrm{D}$ & & $0.068^{* *}$ & & & \\
\hline & & & $(0.032)$ & & & \\
\hline \multirow[t]{2}{*}{ three children +} & $\mathrm{D}$ & & 0.071 & & & \\
\hline & & & $(0.054)$ & & & \\
\hline \multirow[t]{2}{*}{ family very important } & $\mathrm{D}$ & & & $0.070^{* *}$ & & $0.077^{* *}$ \\
\hline & & & & $(0.028)$ & & $(0.033)$ \\
\hline \multirow[t]{2}{*}{ unsatisfied social benefits } & $\mathrm{D}$ & & & -0.006 & & 0.006 \\
\hline & & & & $(0.018)$ & & $(0.019)$ \\
\hline \multirow[t]{2}{*}{ security conscious } & & & & 0.001 & & -0.001 \\
\hline & & & & $(0.005)$ & & $(0.005)$ \\
\hline \multirow[t]{2}{*}{ health satisfaction } & & & & -0.000 & & 0.001 \\
\hline & & & & $(0.004)$ & & $(0.004)$ \\
\hline \multirow[t]{2}{*}{ classical concerts, theatre } & $\mathrm{D}$ & & & & -0.038 & \\
\hline & & & & & $(0.031)$ & \\
\hline \multirow[t]{2}{*}{ pop concerts, movies, discos } & $\mathrm{D}$ & & & & 0.017 & \\
\hline & & & & & $(0.028)$ & \\
\hline \multirow[t]{2}{*}{ active sports } & $\mathrm{D}$ & & & & -0.036 & \\
\hline & & & & & $(0.028)$ & \\
\hline \multirow[t]{2}{*}{ meet friends, neighbors } & $\mathrm{D}$ & & & & 0.025 & \\
\hline & & & & & $(0.020)$ & \\
\hline \multirow[t]{2}{*}{ help friends, neighbors } & $\mathrm{D}$ & & & & 0.018 & \\
\hline & & & & & $(0.019)$ & \\
\hline \multirow[t]{2}{*}{ attend church services } & $\mathrm{D}$ & & & & -0.023 & \\
\hline & & & & & $(0.035)$ & \\
\hline $\mathrm{N}$ & & 2,049 & 2,049 & 2,024 & 2,049 & 1,715 \\
\hline Pseudo-R2 & & 0.145 & 0.145 & 0.145 & 0.148 & 0.064 \\
\hline$\chi^{2}$ & & 306.4 & 306.3 & 300.1 & 307.7 & 107.0 \\
\hline $\mathrm{p}$ & & 0.000 & 0.000 & 0.000 & 0.000 & 0.000 \\
\hline $\mathrm{AIC}$ & & $2,108.8$ & $2,112.7$ & $2,082.5$ & $2,114.2$ & $1,689.6$ \\
\hline BIC & & $2,249.5$ & $2,264.6$ & $2,245.2$ & $2,288.6$ & $1,847.6$ \\
\hline
\end{tabular}

D indicates dummy variables. Average marginal effects are reported. Standard errors are reported in parentheses. ${ }^{* * *},{ }^{* *}, *$ indicate significance at the $0.01,0.05,0.1$ level. 


\section{CESifo Working Paper Series}

for full list see www.cesifo-group.org/wp

(address: Poschingerstr. 5, 81679 Munich, Germany, office@cesifo.de)

2977 Johann K. Brunner and Susanne Pech, Optimum Taxation of Bequests in a Model with Initial Wealth, March 2010

2978 Guglielmo Maria Caporale and Nicola Spagnolo, Stock Market Integration between three CEECs, Russia and the UK, March 2010

2979 Florian Englmaier, Ales Filipi and Ravi Singh, Incentives, Reputation and the Allocation of Authority, March 2010

2980 Konstantinos Angelopoulos, George Economides and Apostolis Philippopoulos, What is the Best Environmental Policy? Taxes, Permits and Rules under Economic and Environmental Uncertainty, March 2010

2981 Frederick van der Ploeg, Rapacious Resource Depletion, Excessive Investment and Insecure Property Rights, March 2010

2982 Wolfram F. Richter and Christoph Braun, Efficient Subsidization of Human Capital Accumulation with Overlapping Generations and Endogenous Growth, March 2010

2983 Francesco Cinnirella, Marc Piopiunik and Joachim Winter, Why Does Height Matter for Educational Attainment? Evidence from German Pre-Teen Children, March 2010

2984 Bernard Van Praag, Well-being Inequality and Reference Groups - An Agenda for New Research, March 2010

2985 Francesca Barion, Raffaele Miniaci, Paolo M. Panteghini and Maria Laura Parisi, Profit Shifting by Debt Financing in Europe, March 2010

2986 Alexander Haupt and Magdalena Stadejek, The Choice of Environmental Policy Instruments: Energy Efficiency and Redistribution, March 2010

2987 John Komlos and Marek Brabec, The Trend of BMI Values among US Adults, March 2010

2988 Emanuele Massetti and Lea Nicita, The Optimal Climate Policy Portfolio when Knowledge Spills across Sectors, March 2010

2989 Helmut Rainer and Thomas Siedler, Family Location and Caregiving Patterns from an International Perspective, March 2010

2990 Toru Kikuchi and Ngo Van Long, A Simple Model of Service Offshoring with Time Zone Differences, March 2010

2991 Assaf Razin, Efraim Sadka and Benjarong Suwankiri, Migration and the Welfare State: Dynamic Political-Economy Theory, March 2010 
2992 Bård Harstad, Buy Coal! Deposit Markets Prevent Carbon Leakage, March 2010

2993 Axel Dreher, Stephan Klasen, James Raymond Vreeland and Eric Werker, The Costs of Favoritism: Is Politically-driven Aid less Effective?, March 2010

2994 Sven Neelsen and Thomas Stratmann, Effects of Prenatal and Early Life Malnutrition: Evidence from the Greek Famine, March 2010

2995 Claude Hillinger and Bernd Süssmuth, The Quantity Theory of Money: An Assessment of its Real Linchpin Prediction, March 2010

2996 Matthew M. Chingos and Martin R. West, Do More Effective Teachers Earn More Outside of the Classroom?, March 2010

2997 Laurence Jacquet and Dirk Van de gaer, A Comparison of Optimal Tax Policies when Compensation or Responsibility Matter, March 2010

2998 Valentina Bosetti, Carlo Carraro, Romain Duval and Massimo Tavoni, What Should we Expect from Innovation? A Model-Based Assessment of the Environmental and Mitigation Cost Implications of Climate-Related R\&D, March 2010

2999 Scott Alan Carson, Nineteenth Century Stature and Family Size: Binding Constraint or Productive Labor Force?, March 2010

3000 Jukka Pirttilä and Ilpo Suoniemi, Public Provision, Commodity Demand and Hours of Work: An Empirical Analysis, March 2010

3001 Bertrand Candelon and Franz C. Palm, Banking and Debt Crises in Europe: The Dangerous Liaisons?, March 2010

3002 Joan Costa-i-Font and Marin Gemmill-Toyama, Does Cost Sharing really Reduce Inappropriate Prescriptions?, March 2010

3003 Scott Barrett, Climate Treaties and Backstop Technologies, March 2010

3004 Hans Jarle Kind, Tore Nilssen and Lars Sørgard, Price Coordination in Two-Sided Markets: Competition in the TV Industry, March 2010

3005 Jay Pil Choi and Heiko Gerlach, Global Cartels, Leniency Programs and International Antitrust Cooperation, March 2010

3006 Aneta Hryckiewicz and Oskar Kowalewski, Why do Foreign Banks Withdraw from other Countries? A Panel Data Analysis, March 2010

3007 Eric A. Hanushek and Ludger Woessmann, Sample Selectivity and the Validity of International Student Achievement Tests in Economic Research, March 2010

3008 Dennis Novy, International Trade and Monopolistic Competition without CES: Estimating Translog Gravity, April 2010 
3009 Yin-Wong Cheung, Guonan Ma and Robert N. McCauley, Renminbising China's Foreign Assets, April 2010

3010 Michel Beine and Sara Salomone, Migration and Networks: Does Education Matter more than Gender?, April 2010

3011 Friedrich Schneider, Tilman Brück and Daniel Meierrieks, The Economics of Terrorism and Counter-Terrorism: A Survey (Part I), April 2010

3012 Friedrich Schneider, Tilman Brück and Daniel Meierrieks, The Economics of Terrorism and Counter-Terrorism: A Survey (Part II), April 2010

3013 Frederick van der Ploeg and Steven Poelhekke, The Pungent Smell of "Red Herrings": Subsoil Assets, Rents, Volatility and the Resource Curse, April 2010

3014 Vjollca Sadiraj, Jan Tuinstra and Frans van Winden, Identification of Voters with Interest Groups Improves the Electoral Chances of the Challenger, April 2010

3015 Guglielmo Maria Caporale, Davide Ciferri and Alessandro Girardi, Time-Varying Spot and Futures Oil Price Dynamics, April 2010

3016 Scott Alan Carson, Racial Differences in Body-Mass Indices for Men Imprisoned in $19^{\text {th }}$ Century US Prisons: A Multinomial Approach, April 2010

3017 Alessandro Fedele, Paolo M. Panteghini and Sergio Vergalli, Optimal Investment and Financial Strategies under Tax Rate Uncertainty, April 2010

3018 Laurence Jacquet, Take it or Leave it: Take-up, Optimal Transfer Programs, and Monitoring, April 2010

3019 Wilhelm Kohler and Jens Wrona, Offshoring Tasks, yet Creating Jobs?, April 2010

3020 Paul De Grauwe, Top-Down versus Bottom-Up Macroeconomics, April 2010

3021 Karl Ove Aarbu, Demand Patterns for Treatment Insurance in Norway, April 2010

3022 Toke S. Aidt and Jayasri Dutta, Fiscal Federalism and Electoral Accountability, April 2010

3023 Bahram Pesaran and M. Hashem Pesaran, Conditional Volatility and Correlations of Weekly Returns and the VaR Analysis of 2008 Stock Market Crash, April 2010

3024 Stefan Buehler and Dennis L. Gärtner, Making Sense of Non-Binding Retail-Price Recommendations, April 2010

3025 Leonid V. Azarnert, Immigration, Fertility, and Human Capital: A Model of Economic Decline of the West, April 2010

3026 Christian Bayer and Klaus Wälde, Matching and Saving in Continuous Time: Theory and 3026-A Matching and Saving in Continuous Time: Proofs, April 2010 
3027 Coen N. Teulings and Nick Zubanov, Is Economic Recovery a Myth? Robust Estimation of Impulse Responses, April 2010

3028 Clara Graziano and Annalisa Luporini, Optimal Delegation when the Large Shareholder has Multiple Tasks, April 2010

3029 Erik Snowberg and Justin Wolfers, Explaining the Favorite-Longshot Bias: Is it RiskLove or Misperceptions?, April 2010

3030 Doina Radulescu, The Effects of a Bonus Tax on Manager Compensation and Welfare, April 2010

3031 Helmut Lütkepohl, Forecasting Nonlinear Aggregates and Aggregates with Timevarying Weights, April 2010

3032 Silvia Rocha-Akis and Ronnie Schöb, Welfare Policy in the Presence of Unionised Labour and Internationally Mobile Firms, April 2010

3033 Steven Brakman, Robert Inklaar and Charles van Marrewijk, Structural Change in OECD Comparative Advantage, April 2010

3034 Dirk Schindler and Guttorm Schjelderup, Multinationals, Minority Ownership and TaxEfficient Financing Structures, April 2010

3035 Christian Lessmann and Gunther Markwardt, Decentralization and Foreign Aid Effectiveness: Do Aid Modality and Federal Design Matter in Poverty Alleviation?, April 2010

3036 Eva Deuchert and Conny Wunsch, Evaluating Nationwide Health Interventions when Standard Before-After Doesn't Work: Malawi’s ITN Distribution Program, April 2010

3037 Eric A. Hanushek and Ludger Woessmann, The Economics of International Differences in Educational Achievement, April 2010

3038 Frederick van der Ploeg, Aggressive Oil Extraction and Precautionary Saving: Coping with Volatility, April 2010

3039 Ainura Uzagalieva, Evžen Kočenda and Antonio Menezes, Technological Imitation and Innovation in New European Union Markets, April 2010

3040 Nicolas Sauter, Jan Walliser and Joachim Winter, Tax Incentives, Bequest Motives, and the Demand for Life Insurance: Evidence from two Natural Experiments in Germany, April 2010 